\title{
Biological Control of Bacterial Speck of Tomato Under Field Conditions at Several Locations in North America
}

\author{
M. Wilson, H. L. Campbell, P. Ji, J. B. Jones, and D. A. Cuppels
}

First author: Biology Department, The Colorado College, Colorado Springs 80903; second and third authors: Department of Plant Pathology and Entomology, Auburn University, Auburn, AL 36849; fourth author: Department of Plant Pathology, University of Florida, Gainesville 32611; and fifth author: Agriculture and Agri-Food Canada, Southern Crop Protection and Food Research Centre, London, Ontario N5V 4T3, Canada.

Accepted for publication 24 July 2002.

\begin{abstract}
Wilson, M., Campbell, H. L., Ji, P., Jones, J. B., and Cuppels, D. A. 2002. Biological control of bacterial speck of tomato under field conditions at several locations in North America. Phytopathology 92:1284-1292.

Bacterial speck of tomato, caused by Pseudomonas syringae pv. tomato, continues to be a problem for tomato growers worldwide. A collection of nonpathogenic bacteria from tomato leaves plus $P$. syringae strains TLP2 and Cit7, P. fluorescens strain A506, and P. syringae pv. tomato DC3000 hrp mutants were examined in a greenhouse bioassay for the ability to reduce foliar bacterial speck disease severity. While several of these strains significantly reduced disease severity, $P$. syringae Cit7 was the most effective, providing a mean level of disease reduction of $78 \%$ under greenhouse conditions. The $P$. syringae pv. tomato DC3000 $h r p A, h r p H$, and $h r p S$ mutants also significantly reduced speck severity

under greenhouse conditions. The strains with the greatest efficacy under greenhouse conditions were tested for the ability to reduce bacterial speck under field conditions at locations in Alabama, Florida, and Ontario, Canada. P. syringae Cit7 was the most effective strain, providing a mean level of disease reduction of $28 \%$ over 10 different field experiments. P. fluorescens A506, which is commercially available as BlightBan A506, provided a mean level of disease reduction of $18 \%$ over nine different field experiments. While neither $P$. syringae Cit7 nor $P$. fluorescens A506 can be integrated with copper bactericides due to their copper sensitivity, there exist some potential for integrating these biological control agents with "plant activators", including Actigard. Of the $P$. syringae pv. tomato DC3000 hrp mutants tested, only the hrpS mutant reduced speck severity significantly under field conditions.
\end{abstract}

Bacterial speck disease of tomato, caused by Pseudomonas syringae pv. tomato, occurs worldwide $(9,11-14,19,23,31,48,51-$ 53,55,56). In North America, bacterial speck is most prevalent in processing tomatoes in the Midwestern United States and Ontario, Canada, and in fresh-market tomatoes in the mountain areas of North Carolina. The disease occurs occasionally in processing tomatoes in California when the spring is particularly cool and wet, and is similarly sporadic in fresh-market tomatoes in Florida and Virginia. Yield reductions result from the reduced photosynthetic capacity of infected foliage and from lesions on the fruit that render them unsuitable for the fresh market.

While copper-based bactericides $(13,16,57,73)$ have been used to control bacterial speck, the rapid development of plasmidmediated copper-tolerance has rendered these compounds relatively ineffective $(1,5,48,56)$. Combining these compounds with the ethylene bisdithiocarbamate (EBDC) fungicides, maneb or mancozeb, has provided improved levels of control even with coppertolerant populations (16). However, these copper-EBDC combinations are only moderately effective and are possibly carcinogenic. The antibiotic streptomycin also has been used to control bacterial speck $(13,16)$, but resistance is common in pathogen populations (55) and thus, the antibiotic is rarely used. The recently introduced "plant activators" appear promising for control of bacterial diseases of fruits and vegetables. One such plant activator, acibenzolar-S-methyl (CGA-245704 or Actigard [Syngenta, Greensboro, $\mathrm{NC}]$ ), provides good control of both speck and spot of tomato $(42,53)$. These first generation plant activators are not the final

Corresponding author: M. Wilson; E-mail address: mwilson@ColoradoCollege.edu

Publication no. P-2002-0923-01R

(C) 2002 The American Phytopathological Society solution, however, since they may also reduce fruit yield when applied at recommended application rates and frequencies and suppress defense pathways effective against insect pests (58).

Resistance to race 0 of $P$. syringae pv. tomato, conferred by the gene Pto $(47,49,50)$, has been introduced into several processing tomato varieties but relatively few fresh-market tomato varieties. Unfortunately, hybrid varieties heterozygous for Pto are not completely resistant to speck $(25,46)$. Furthermore, the Pto gene normally does not confer resistance to race 1 of the pathogen $(9,24,31)$ and will not confer disease resistance where this race is present (19). Transgenic plants overexpressing either Pto (59) or Prf (46) appear to be resistant to this race, however, it remains to be seen whether such transgenic lines will be commercialized.

In recent years, there has been substantial interest in the biological control of plant pathogens $(3,41,67-70,72)$. While biological control agents have been introduced successfully into commercial horticulture for control of crown gall (10), caused by Agrobacterium tumefaciens, and fire blight of pear (39), caused by Erwinia amylovora, commercial biological control of diseases caused by pathovars of $P$. syringae has not yet been implemented. However, frost injury caused by ice nucleation active $\left(\mathrm{Ice}^{+}\right) P$. syringae strains can be reduced substantially by applying nonpathogenic non-ice nucleation active (Ice $\left.{ }^{-}\right) P$. syringae strains (33-37) or other Ice $^{-}$organisms such as P. fluorescens A506 (BlightBan A506) (39). Biological control of frost injury is effective because the incidence of frost injury is proportional to the logarithm of the population size of $\operatorname{Ice}^{+} P$. syringae (38), and prior colonization of a leaf or blossom by an $\mathrm{Ice}^{-}$organism reduces the attainable population size of an immigrant Ice $^{+} P$. syringae (33, 36). In theory, it should be possible to use this process called preemptive competitive exclusion to control any bacterial disease in which incidence and/or severity are related to the population 
size of the pathogen on the leaf or blossom surface. Such a relationship has been demonstrated for P. syringae pv syringae (32), but not for $P$. syringae pv. tomato though this pathogen has been reported to colonize tomato leaf surfaces "epiphytically" $(2,6,24$, $44,54,57,66)$. Although small-scale biological control experiments have been performed for several $P$. syringae pathovars including $P$. syringae pv. glycinea on soybean $(43,63-65)$, $P$. syringae pv. savastanoi on olive $(62), P$. syringae pv. syringae on barley $(7,8)$ and bean (40), and $P$. syringae pv. tomato $(4,12-15,17)$, no largescale, multilocation field trials, such as the one described in this study, have been reported.

In this study, a greenhouse assay was used to evaluate the ability of nonpathogenic leaf-associated bacteria to reduce bacterial speck disease severity, and those strains with the most potential as biological control agents were tested under field conditions at multiple locations in North America. In addition to nonpathogenic bacteria isolated from tomato foliage, we tested the following: $P$. fluorescens A506, which previously had been shown to preemptively exclude Ice ${ }^{+} P$. syringae strains and control frost injury (39); $P$. syringae strains TLP2 and Cit7 $(35,36)$ because of the assumption that these closely related bacteria may be effective in preemptive exclusion of $P$. syringae pv. tomato; and hrp mutants of $P$. syringae pv. tomato because studies with undefined avirulent mutants $(40,60-62)$ and hrp mutants $(20-22,45)$ of other bacterial phytopathogens have shown that these strains are potential biological control agents. Our field studies also included Actigard and combinations of Actigard with either P. syringae Cit7 or $P$. fluorescens A506.

\section{MATERIALS AND METHODS}

Bacterial strains. Nonpathogenic bacteria were isolated from symptomless tomato leaves in Alabama (AL) and Florida (FL) on tryptic soy agar (TSA, Difco Laboratories, Detroit, MI) containing $100 \mu \mathrm{g} / \mathrm{ml}$ of cycloheximide to suppress fungi. Bacteria were tentatively identified using the Sherlock GC-FAME system (MIDI Inc., Newark, DE) and stored at $-80^{\circ} \mathrm{C}$ in tryptic soy broth (TSB, Difco Laboratories) containing sterile $20 \%$ (vol/vol) glycerol. Bacterial strains $P$. fluorescens A506 (39), P. syringae TLP2, and $P$. syringae Cit7 (35) were provided by S. E. Lindow (University of California, Berkeley). BlightBan A506 was provided by S. Kelly (Plant Health Technologies, Boise, ID). P. syringae pv. tomato strain PT12 was isolated from tomatoes in California and was provided by D. A. Cooksey (University of California, Riverside). P. syringae pv. tomato strain DCT6D1 was isolated in Leamington, Ontario, Canada (18). P. syringae pv. tomato strain DC3000 was isolated in the United Kingdom (18). The hrp mutants (hrpA, hrpH, and hrpS) of P. syringae pv. tomato DC3000 were provided by S. Y. He (Michigan State University, East Lansing).

Greenhouse experiments. Tomato (cv. Agriset 761) seeds were sown in $3 \times 3 \times 4$-cm cell packs containing Promix (Premier, Red Hill, PA). After 2 to 3 weeks, seedlings were transplanted in $10.2-\mathrm{cm}$ square plastic pots. Plants were maintained with weekly fertilization alternating 15-16-17 complete fertilizer with 15-5-15 N-P-K. Four- to five-week-old tomato plants (approximately 15 to $20 \mathrm{~cm}$ high) were placed under intermittent mist on a greenhouse bench for $24 \mathrm{~h}$ prior to inoculation with potential biological control agents. All bacterial strains were cultured on TSA at $28^{\circ} \mathrm{C}$ for $24 \mathrm{~h}$, except A506, TLP2, Cit7, and DC3000 hrp mutants, which were cultured on King's medium B (29) amended with rifampicin at $100 \mu \mathrm{g} / \mathrm{ml}$. Bacteria were suspended in sterile phosphate buffer (0.01 M, pH 7.0), and suspensions were adjusted to $1 \times 10^{8} \mathrm{CFU} / \mathrm{ml}$ using a spectrophotometer. Suspensions were inoculated on the abaxial and adaxial surfaces of tomato leaves until runoff using a hand-held sprayer, and plants were incubated under intermittent mist for $24 \mathrm{~h}$. Treatments were arranged in a randomized complete block (RCB) design with four replications (where each replicate consisted of a single plant). Plants were subsequently challenged with a suspension of the pathogen $P$. syringae pv. tomato strain PT12, except for experiments with hrp mutants, which were challenged with the wild-type parent DC3000, at a concentration of $1 \times 10^{8} \mathrm{CFU} / \mathrm{ml}$. Plants were incubated under intermittent mist until symptom appearance, at which time the misting was terminated.

Ten leaflets were randomly sampled from each of the four plants per treatment on a single occasion between 7 and 10 days after inoculation with the pathogen. Lesions were counted, and leaf area determined for each leaflet using an image analysis system (Agvision, Decagon Devices, Inc., Pullman, WA). Disease severity data $\left[\log _{10}\left((\right.\right.$ lesions +1$\left.\left.) / \mathrm{cm}^{2}\right)\right]$ were analyzed by analysis of variance (ANOVA) or GLM procedures of SAS (SAS Institute, Cary, NC). Means were compared using Duncan's Multiple Range (DMR) test at $P=0.05$. Bacterial strains that provided the highest level of disease reduction (compared to the pathogen-only control) were selected for field experiments.

Field experiments. Field experiments were conducted in Shorter, AL (spring 1996, 1997, and 1998), Bradenton, FL (spring 1996 and 1997), and London, ON, Canada (ON) (spring 1996 and 1997). Five- to six-week-old transplants were planted in raised beds covered with polyethylene mulch, which had been fumigated with $98 \%$ methyl bromide at $400 \mathrm{lb} / \mathrm{A}(450 \mathrm{~kg} / \mathrm{ha})$ (AL and FL), or bare ground $(\mathrm{ON})$ and placed $0.5 \mathrm{~m}$ apart on $1.2-\mathrm{m}$ centers. Plants were irrigated through drip irrigation (AL) or sip irrigation (FL), and fertilizer was applied at recommended rates through the same system. Field plots were arranged either in an RCB design with five (AL and FL) or four (ON-1997) replications or in a Latin square design with four replications (ON-1996). Bacteria were grown on TSA or King's medium B (AL and FL) for $24 \mathrm{~h}$ at $28^{\circ} \mathrm{C}$ prior to inoculation, washed from plates, and suspended in phosphate buffer $(0.03 \mathrm{M}, \mathrm{pH} 7.4)$. Suspensions were adjusted to a concentration of $1 \times 10^{8} \mathrm{CFU} / \mathrm{ml}$ using a spectrophotometer. The suspensions were applied weekly to tomato foliage using a $\mathrm{CO}_{2^{-}}$ powered backpack sprayer until leaves were visibly wet. In ON, bacteria were grown in nutrient broth (18) at $25^{\circ} \mathrm{C}$ overnight on a shaker ( $150 \mathrm{rpm}$ ) to 2 to $4 \times 10^{9} \mathrm{CFU} / \mathrm{ml}$, pelleted by centrifugation, and resuspended in sterile distilled water to 3 to $6 \times 10^{8} \mathrm{CFU} / \mathrm{ml}$. The suspensions were applied weekly to tomato foliage using an RL-FLO-Master (Root-Lowell Mfg. Co., Lowell, MI) sprayer until leaves were visibly wet. The chemical treatments, copper alone, copper plus an EBDC, or Actigard were applied according to label specifications. Biological and chemical treatments were applied 8 to 10 times during the season. Field plots were inoculated with a suspension of $P$. syringae pv. tomato strain PT12 (AL) or DCT6D1 (ON). Natural infection was present in FL, but where no disease was seen, plants were inoculated once with $P$. syringae pv. tomato strain PT12 $\left(\approx 10^{8} \mathrm{CFU} / \mathrm{ml}\right)$. Field experiments in ON were conducted under permit (Health Canada Research Permit No. 58RP-96). Field experiments in AL with $P$. syringae pv. tomato strain DC3000 hrp mutants were conducted under permit (APHIS 97-023-01r).

In the AL field trials, foliar disease severity was rated either visually as a percentage of necrotic foliage (0 to 100\%) per replicate row (1996) or by sampling 20 to 50 leaflets per replicate row and counting lesions (1996, 1997, and 1998). Incidence was based on the presence or absence of lesions on sampled leaflets (1996). In ON, foliar disease incidence was expressed as the number of leaflets out of 50 showing speck-like lesions (24 50-leaflet samples per treatment), and disease severity was expressed as the number of speck-like lesions on 20 randomly sampled leaflets (16 20-leaflet samples per treatment). In FL, foliar severity was based on a Horsfall-Barratt scale where: $1=0 \% ; 2=0$ to $3 \% ; 3=$ 3 to $6 \% ; 4=6$ to $12 \% ; 5=12$ to $25 \% ; 6=25$ to $50 \%$; and $12=$ $100 \%$ defoliation.

Determination of bacterial population sizes. In AL, $P$. fluorescens A506, $P$. syringae TLP2, and $P$. syringae Cit7 population dynamics were determined to assess the ability of these 
biological control agents to survive on tomato foliage under field conditions. As plants were inoculated weekly with the biological control agents, leaflets were sampled immediately prior to inoculation to assess survival since the last inoculation. Five leaflets per replicate row per treatment (a total of 25 leaves per treatment) were sampled randomly, placed individually in sterile plastic bags, and transported back to the laboratory on ice. Twenty milliliters of sterile phosphate buffer $(0.01 \mathrm{M}, \mathrm{pH} 7.0)$ was added to each bag. Leaflets were sonicated for $10 \mathrm{~min}$ to dislodge bacterial cells and agitated briefly to suspend the bacterial cells. The washwater was diluted by an amount appropriate to the sample and plated on King's medium B amended with rifampicin at $100 \mu \mathrm{g} / \mathrm{ml}$ and cycloheximide at $100 \mu \mathrm{g} / \mathrm{ml}$ using a spiral plater (Autoplate 3000, Spiral Biotech, Bethesda, MD). Following incubation for $72 \mathrm{~h}$ at $28^{\circ} \mathrm{C}$, colonies were enumerated using a laser counter (Spiral Biotech).

In ON, two 10-g leaf samples were randomly collected from the 40 plants of each replicate of each treatment at selected times (as indicated in the Figures) throughout the growing season. Each 10 -g sample was assayed for $P$. syringae pv. tomato populations as described previously (18). The P. fluorescens A506 populations were determined by plating the various sample dilutions on King's medium B amended with rifampicin at $50 \mu \mathrm{g} / \mathrm{ml}$, streptomycin at $10 \mu \mathrm{g} / \mathrm{ml}$, and cycloheximide at $75 \mu \mathrm{g} / \mathrm{ml}$.

\section{RESULTS}

Greenhouse experiments. $P$. fluorescens A506, $P$. syringae TLP2, and $P$. syringae Cit7 provided moderate to high levels of disease control in all greenhouse experiments. Over the course of 14 to 17 experiments in the greenhouse, Cit7 provided a mean level of control of $78.4 \%$ (standard deviation $(\mathrm{SD})=8.9 \%$ ), A506 provided a mean level of control of $61.2 \%(\mathrm{SD}=16.4 \%)$, and TLP2 provided a mean level of control of $59.8 \%(\mathrm{SD}=15.5 \%)$ (data not shown). Not only did Cit7 provide a significantly $(P<$ 0.0001 ) higher mean level of disease control than TLP2 or A506, but the variability in the level of control as measured by standard deviation was also considerably less. During these experiments, the mean level of disease severity in the pathogen-only control varied between approximately 0.3 and 2.5 lesions per $\mathrm{cm}^{2}$ perhaps due to fluctuating conditions in the greenhouse. There was, however, no significant correlation between the level of control provided by these three biological control agents and the disease severity in the pathogen-only control (data not shown).

Approximately 70 nonpathogenic bacterial strains isolated from tomato foliage were tested in the greenhouse assay for the ability to reduce bacterial speck disease severity. From this first round of screening of the 70 strains, four were selected for field studies in AL and FL during that year (1996) based upon the level of disease reduction being equal to or greater than that provided by Cit7, TLP2, and A506: $\mathrm{Cu} 9$ (69.4\% reduction), $\mathrm{Cu} 14$ (71.0\% reduction), B52 (73.3\% reduction), and B41 (79.5\% reduction) (data for other strains not shown). A subset of 36 of these 70 strains, including $\mathrm{Cu} 9, \mathrm{Cu} 14, \mathrm{~B} 52$, and B41, were tested in an additional two experiments and the mean level of disease reduction across three experiments was calculated: $\mathrm{Cu} 14$ (mean $28.6 \%$ reduction), $\mathrm{Cu} 9$ (mean $48.2 \%$ reduction), B52 (mean $56.2 \%$ reduction), and B41 (mean 65\% reduction) (data for other strains not shown).

Under greenhouse conditions, the $P$. syringae pv. tomato strain DC3000 hrp mutants provided significant $(P=0.05)$ reductions in bacterial speck severity, however, none of the $h r p$ mutants were as effective as Cit7, TLP2, or A506 (data not shown). Since the hrp mutants provided significant reductions in severity, they were employed in a field experiment in 1997.

Field experiments: 1996. The four nonpathogenic bacterial strains, $\mathrm{Cu} 9, \mathrm{Cu} 14, \mathrm{~B} 52$, and B41 that were selected from the first round of screening, and strains Cit7, TLP2, and A506 were tested for efficacy against bacterial speck under field conditions in AL and FL (Tables 1 and 2). Due to regulatory constraints, only Cit7, TLP2, and A506 were included in the field experiments in ON (Table 3). Copper-based bactericides, alone or in combination with mancozeb, were included for comparison. Since the mean level of reduction in disease provided by $\mathrm{Cu} 9, \mathrm{Cu} 14, \mathrm{~B} 52$, and B41 in greenhouse experiments was much lower than the initial level determined during the single round of screening, and since the levels of control in the field (Tables 1 and 2) were, in general, not superior to those provided by the well characterized strains Cit7, TLP2, and A506, it was decided not to include these strains in subsequent field experiments.

Field experiments: 1997. In 1997, experiments were conducted successfully in only AL and ON (Tables 4 and 5). The experiment in AL incorporated the P. syringae pv. tomato DC3000 hrp mutants in addition to Cit7, TLP2, and A506 (Table 4). Additionally, $P$. putida B56 that provided a mean level of control in the greenhouse of $61 \%$ (mean of three experiments), and was also effective against the bacterial spot pathogen (M. Wilson, J. M. Byrne, H. L. Campbell, A. C. Dianese, J. B. Jones, and D. A. Cuppels, unpublished data) was incorporated into this experiment (Table 4). Of the $P$. syringae pv. tomato DC3000 hrp mutants, only the hrpS mutant significantly $(P=0.05)$ reduced disease severity and then only in the first disease assessment. Since the hrp mutants did not show the potential to provide higher levels of control of speck than the well-characterized strains Cit7, TLP2, and A506, they were not included in subsequent field experiments.

TABLE 1. Efficacy of biological control agents in the control of bacterial speck (foliar incidence, foliar severity, and fruit incidence) on tomato (cv. Agriset 761) in a field experiment conducted in Alabama (spring 1996)

\begin{tabular}{|c|c|c|c|c|c|}
\hline & Foliar incidence $^{t}$ & Foliar severity ${ }^{\mathrm{u}}$ & Foliar incidence $^{\mathrm{v}}$ & Foliar severity ${ }^{\mathrm{w}}$ & Fruit incidence ${ }^{\mathrm{x}}$ \\
\hline Control & $71.1 \mathrm{a}^{\mathrm{y}}$ & $18.3 \mathrm{a}^{\mathrm{y}}$ & $60.1 \mathrm{a}^{\mathrm{y}}$ & $28.8 \mathrm{a}^{\mathrm{y}}$ & $1.7 \mathrm{a}^{\mathrm{y}}$ \\
\hline Kocide DF & $29.2 \mathrm{c}(71.2)^{\mathrm{z}}$ & $3.3 \mathrm{c}(81.9)^{\mathrm{z}}$ & $37.9 \mathrm{~d}(49.1)^{\mathrm{z}}$ & $15.0 \mathrm{~cd}(70.2)^{\mathrm{z}}$ & $0.5 \mathrm{a}(56.1)^{\mathrm{z}}$ \\
\hline BlightBan A506 & $46.5 \mathrm{~b}(37.5)$ & 11.7 abc $(36.0)$ & 47.7 c (26.7) & $23.3 \mathrm{ab}(34.7)$ & $1.3 \mathrm{a}(32.9)$ \\
\hline Pseudomonas fluorescens A506 & $49.9 \mathrm{~b}(30.7)$ & $15.8 \mathrm{ab}(13.6)$ & $54.0 \mathrm{abc}(12.4)$ & $26.7 \mathrm{ab}(14.0)$ & 0.9 a $(34.8)$ \\
\hline P. syringae TLP2 & $50.8 \mathrm{~b}(28.6)$ & $15.8 \mathrm{ab}(13.6)$ & 51.9 abc (16.9) & $25.4 \mathrm{ab}(20-.6)$ & 0.8 a $(51.7)$ \\
\hline P. syringae $\mathrm{Cit} 7$ & $46.5 \mathrm{~b}(37.5)$ & $8.2 \mathrm{bc}(55.2)$ & 49.7 bc (22.2) & 20.9 abcd $(45.0)$ & $0.3 \mathrm{a}(80.4)$ \\
\hline B41 & $49.3 \mathrm{~b}(31.6)$ & $13.3 \mathrm{ab}(27.3)$ & $52.4 \mathrm{abc}(16.1)$ & $23.3 \mathrm{ab}(34.7)$ & $1.6 \mathrm{a}(0)$ \\
\hline B52 & $50.4 \mathrm{~b}(29.6)$ & $15.5 \mathrm{ab}(15.3)$ & $59.8 \mathrm{a}(1.0)$ & 19.8 bcd (48.3) & $0.5 \mathrm{a}(52.0)$ \\
\hline $\mathrm{Cu} 9$ & $51.4 \mathrm{~b}(27.7)$ & $13.3 \mathrm{ab}(27.3)$ & $59.4 \mathrm{ab}(1.0)$ & $20.0 \mathrm{bcd}(41.3)$ & 0.4 a (67.6) \\
\hline $\mathrm{Cu} 14$ & $52.5 \mathrm{~b}(25.6)$ & $14.2 \mathrm{ab}(22.4)$ & $51.6 \mathrm{abc}(17.8)$ & $23.6 \mathrm{ab}(27.7)$ & 0.4 a (71.6) \\
\hline
\end{tabular}

t Sample of 20 leaflets per replicate taken 4 June 1996.

u Visual ratings of foliar disease severity (0 to 100\%) made 6 June 1996.

v Sample of 50 leaves per replicate taken 6 June 1996.

${ }^{\mathrm{w}}$ Visual ratings of foliar disease severity (0 to 100\%) made 12 June 1996.

x Percent infected fruit based on a complete harvest made 13 June 1996.

y Means in a column followed by the same letter are not significantly different at $P=0.05$ according to Duncan's multiple range test.

${ }^{\mathrm{z}}$ Percent disease reduction compared to pathogen-only control. 
The experiment in ON incorporated Paenibacillus sp. BC87, which provided moderate levels of control in separate greenhouse experiments in ON (data not shown), in addition to Cit7 and A506 (Table 5). This was also the first experiment to attempt to integrate $P$. fluorescens A506 and Actigard. In the first disease assessment, the level of disease reduction achieved by this combination was significantly $(P=0.05)$ higher than that provided by Actigard alone, warranting inclusion of such combination treatments in the 1998 field experiments.

Field experiments: 1998. In 1998, two experiments were conducted successfully in AL (Tables 6 and 7). These experiments incorporated only Cit7, TLP2, A506, or those strains in combination with Actigard (applied at recommended rates). Only in one disease assessment was the level of disease reduction achieved by a biological control agent in combination with Actigard significantly $(P=0.05)$ higher than that provided by Actigard alone (i.e., Cit7 plus Actigard [Table 7]).

Field experiments: Summary. Across all the field experiments, under different climatic conditions and horticultural practices, and with different application methods and users, $P$. syringae strain Cit7 was the most effective biological control agent providing a mean reduction in bacterial speck severity of $28.3 \%$, compared to 18.0 and $14.9 \%$ for A506 and TLP2, respectively (Table 8). In contrast to the greenhouse studies, however, the variability was not considerably lower for Cit7 than for the other two strains (Table 8).

Population dynamics of biological control agents. The population dynamics of the biological control agents were determined

TABLE 2. Efficacy of biological control agents in the control of bacterial speck (foliar incidence and severity) on tomato (cv. Agriset) in a field experiment conducted in Florida (spring 1996)

\begin{tabular}{|c|c|c|c|}
\hline & $\begin{array}{c}\text { Foliar } \\
\text { severity }{ }^{\mathrm{u}, \mathrm{v}}\end{array}$ & $\begin{array}{c}\text { Foliar } \\
\text { severity }^{\mathrm{u}, \mathrm{w}}\end{array}$ & Lesions/leaflet ${ }^{\mathrm{u}, \mathrm{x}}$ \\
\hline Control & $4.9 \mathrm{a}^{\mathrm{y}}$ & 3.9 & $10.2 \mathrm{a}^{\mathrm{y}}$ \\
\hline BlightBan A506 & $4.9 \mathrm{a}$ & 4.0 & $7.7 \mathrm{ab}(24.5)^{\mathrm{z}}$ \\
\hline Pseudomonas syringae TLP2 & $4.9 \mathrm{a}$ & 3.9 & $7.3 \mathrm{ab}(28.4)$ \\
\hline P. syringae $\mathrm{Cit} 7$ & $4.8 \mathrm{a}$ & 4.0 & $7.7 \mathrm{ab}(24.5)$ \\
\hline P. fluorescens A506 & $4.9 \mathrm{a}$ & 3.9 & $7.8 \mathrm{ab}(23.5)$ \\
\hline B41 & $4.7 \mathrm{a}$ & 3.8 & $8.5 \mathrm{ab}(16.7)$ \\
\hline B52 & $4.8 \mathrm{a}$ & 3.6 & $8.9 \mathrm{ab}(12.7)$ \\
\hline $\mathrm{Cu} 9$ & $4.7 \mathrm{a}$ & 3.9 & $6.0 \mathrm{ab}(41.2)$ \\
\hline $\mathrm{Cu} 14$ & $4.8 \mathrm{a}$ & 3.7 & $5.5 \mathrm{ab}(46.1)$ \\
\hline Kocide 101 & $4.6 \mathrm{a}$ & 3.8 & $6.2 \mathrm{~b}(39.2)$ \\
\hline
\end{tabular}

u Rating is based on Horsfall-Barratt scale where: $1=0 \% ; 2=0$ to $3 \% ; 3=3$ to $6 \% ; 4=6$ to $12 \% ; 5=12$ to $25 \% ; 6=25$ to $50 \% ; 12=100 \%$ defoliation. ${ }^{v}$ Rating made on 9 April 1996.

${ }^{\text {w }}$ Rating made on 26 April 1996.

x Ten leaflets from each plot were selected, and lesions were counted on each leaflet. The data were log-transformed prior to analysis.

${ }^{y}$ Means in a column followed by the same letter are not significantly different at $P=0.05$ according to a Duncan's multiple range test.

${ }^{\mathrm{z}}$ Percent disease reduction compared to pathogen-only control. to assess the survival of these organisms under different environmental conditions and horticultural practices. In AL, the biological control agents were applied on a weekly basis; leaflet samples to assess population sizes were taken just prior to that application (i.e., population size on the leaves represents that which persisted from the inoculation 7 days prior to the sampling). P. syringae strain TLP2 reached a slightly higher population size on tomato foliage than did P. fluorescens A506 in 1995 (Fig. 1A), and TLP2 and Cit7 reached slightly higher population sizes than A506 in 1996 (Fig. 1B), however, these differences were not statistically significant. In 1995, TLP2 maintained a peak population size of approximately $1 \times 10^{4} \mathrm{CFU} /$ leaflet while A506 maintained a peak population size of approximately $2 \times 10^{3} \mathrm{CFU} /$ leaflet (Fig. 1A). In 1996, Cit7 and TLP2 maintained a peak population size of approximately $3.2 \times 10^{4} \mathrm{CFU} /$ leaflet, while A506 increased throughout the season reaching approximately $1.6 \times 10^{4} \mathrm{CFU} /$ leaflet (Fig. 1B).

In $\mathrm{ON}$, the population size of $P$. fluorescens A506 increased slowly throughout the season and reached approximately $1 \times$ $10^{5}$ CFU/g fresh weight in 1996 (Fig. 2) and approximately $3.2 \times$ $10^{3}$ CFU/g fresh weight 1997 (Fig. 3A) (Cit7 and TLP2 population sizes were not measured in $\mathrm{ON}$ ).

Population dynamics of the pathogen. In $\mathrm{ON}$, the population dynamics of $P$. syringae pv. tomato were determined on the foliage of plants treated with different biological control agents in order to provide another measure of efficacy (1996-Fig. 2; 1997Fig. 3B). The only treatment that significantly reduced epiphytic pathogen population sizes was the Actigard/A506 combination used in 1997 (Fig. 3B).

\section{DISCUSSION}

The data presented in this study suggest that while there is potential for biological control of bacterial speck of tomato due to the relatively moderate levels of disease control achieved, any future use of foliar biological control agents is likely to be just one component of an integrated disease management program. The most effective biological control agent, bacterial strain $P$. syringae Cit7, achieved 15 to $50 \%$ reduction in foliar disease severity with a mean of $28 \%$ reduction when used in different tomato-growing regions of North America (AL, FL, and ON), under different climatic conditions, on different cultivars with different horticultural practices (including fungicide regimes), and different users. $P$. syringae Cit7 maintained an effective population size on the tomato leaflets when applied only once a week; a regime comparable to current chemical application frequencies. Unfortunately, Cit7 did not reduce the incidence of bacterial speck lesions on the fruit in either of the experiments in which this parameter was measured. Neither did Cit7 significantly reduce epiphytic population sizes of $P$. syringae pv. tomato in two different experiments in ON (Figs. 2 and 3B). This might suggest that incidence of speck on the fruit is correlated with epiphytic population size of $P$. syringae pv. tomato and not with foliar lesion number; hence,

TABLE 3. Efficacy of biological control agents in the control of bacterial speck (foliar and fruit incidence) on tomato (cv. H9478) in a field experiment conducted in London, Ontario, Canada (summer 1996)

\begin{tabular}{|c|c|c|c|c|}
\hline & Foliar incidence $^{v}$ & Foliar severity ${ }^{\mathrm{w}}$ & Foliar incidence $^{\mathrm{x}}$ & Fruit yield (kg/10 plants) \\
\hline Control & $40.5 \mathrm{a}^{\mathrm{y}}$ & $182.0 \mathrm{a}^{\mathrm{y}}$ & $28.4 \mathrm{a}^{\mathrm{y}}$ & $44.3 \mathrm{a}^{\mathrm{y}}$ \\
\hline BlightBan A506 & $33.3 \mathrm{c}(17.8)^{\mathrm{z}}$ & $128.4 b(29.5)^{z}$ & $21.2 \mathrm{a}(25.4)^{\mathrm{z}}$ & $46.9 \mathrm{a}$ \\
\hline Pseudomonas syringae TLP2 & $37.4 \mathrm{~b}(7.7)$ & $172.8 \mathrm{a}(5.1)$ & 22.6 a (20.4) & $45.6 \mathrm{a}$ \\
\hline
\end{tabular}

${ }^{v}$ Samples of 50 leaves per replicate taken 6 August 1996 (56 days after transplanting). Each number represents the mean number of leaves out of 50 showing bacterial speck-like symptoms.

${ }^{\text {w Samples of }} 20$ leaves per replicate taken 6 August 1996. Each number represents the mean number of bacterial speck-like lesions present in each 20-leaf sample.

x Tomatoes were harvested on 12 September 1996 (101 days after transplanting), assessed for bacterial speck-like lesions, and weighed.

${ }^{y}$ Means in a column followed by the same letter are not significantly different at $P=0.05$ according to Duncan's multiple range test.

${ }^{\mathrm{z}}$ Percent disease reduction compared to pathogen-only control. 
although Cit7 reduced foliar disease severity, there was no impact on incidence of disease on the fruit.

The data presented here justify further investigation of the effect of Cit7 on the marketable tomato yield. It should be noted that while by most standards $P$. syringae Cit7 could be considered a successful biological control agent, particularly since it has also been shown to reduce bacterial spot severity (M. Wilson, J. M. Byrne, H. L. Campbell, A. C. Dianese, J. B. Jones, and D. A. Cuppels, unpublished data), unless marketable yield is increased, this strain likely has no potential for commercial development. Marketable yield is determined by total yield and the incidence of speck on the fruit. Even if Cit7 did not reduce speck incidence on the fruit (which remains to be confirmed), reduction of foliar disease could increase the total yield (despite the fact that tomatoes can tolerate a certain degree of defoliation) or reduce the number of fruit lost to sun-scald due to the reduction in defoliation. Of course, the fact that Cit7 is an $\mathrm{Ice}^{+}$strain means that any commercial biological control agent developed from the strain could be utilized only after any threat of frost has passed.

As the most effective biological control agent of bacterial speck (this study) and bacterial spot (M. Wilson, J. M. Byrne, H. L. Campbell, A. C. Dianese, J. B. Jones, and D. A. Cuppels, unpublished data) to date, $P$. syringae Cit7 is now the subject of investigations to improve overall efficacy through various approaches, including combined application of Cit7 and salicylic acid (27), which induces systemic acquired resistance (SAR) in tomato (11); enhanced colonization of Cit7 through the use of an engineered salicylic acid-catabolizing Cit7 strain and exogenous salicylic acid (27), or an engineered opine-catabolizing Cit7 strain and transgenic opine-producing plants (72); and through the foliar-applica-

TABLE 4. Efficacy of biological control agents in the control of bacterial speck (foliar severity) on tomato (cv. Agriset 761) in a field experiment conducted in Alabama (spring 1997)

\begin{tabular}{lcl}
\hline & Foliar severity $^{\mathrm{w}}$ & Foliar severity $^{\mathrm{x}}$ \\
\hline Control & $1.29 \mathrm{a}^{\mathrm{y}}$ & $1.44 \mathrm{ab}^{\mathrm{y}}$ \\
Pseudomonas putida B56 & $0.98 \mathrm{~b}(24.0)^{\mathrm{z}}$ & $1.49 \mathrm{ab}(0)^{\mathrm{z}}$ \\
BlightBan A506 & $1.07 \mathrm{~b}(17.0)$ & $1.41 \mathrm{ab}(2.1)$ \\
P. syringae TLP2 & $0.99 \mathrm{~b}(23.2)$ & $1.35 \mathrm{~b}(6.2)$ \\
P. syringae Cit7 & $1.03 \mathrm{~b}(20.2)$ & $1.30 \mathrm{~b}(9.7)$ \\
DC3000 hrpS & $1.10 \mathrm{~b} \mathrm{(14.7)}$ & $1.35 \mathrm{~b}(6.3)$ \\
DC3000 hrpH & $1.31 \mathrm{a}(0)$ & $1.38 \mathrm{ab}(4.2)$ \\
DC3000 hrpA & $1.28 \mathrm{a}(0)$ & $1.43 \mathrm{ab}(0)$ \\
Kocide + Manex & $0.69 \mathrm{c}(46.5)$ & $0.94 \mathrm{c}(34.7)$ \\
Actigard & $0.46 \mathrm{~d}(64.3)$ & $0.80 \mathrm{~d}(43.8)$ \\
\hline
\end{tabular}

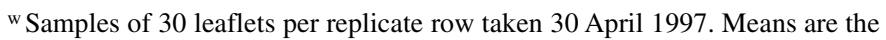
$\log$ of the number of lesions per leaflet.

x Samples of 30 leaflets per replicate row taken 7 May 1997. Means are the $\log$ of the number of lesions per leaflet.

y Means in a column followed by the same letter are not significantly different at $P=0.05$ according to Duncan's multiple range test.

${ }^{\mathrm{z}}$ Percent disease reduction compared to pathogen-only control. tion of Cit7 in conjunction with root-application of rhizobacteria which induce systemic resistance (26; P. Ji, H. L. Campbell, J. W. Kloepper, J. B. Jones, T. Suslow, and M. Wilson, unpublished data).

The bacterial strain $P$. syringae TLP2 was less effective than Cit7 under both greenhouse and field conditions. This is despite the fact that the Ice ${ }^{-}$derivatives of the two strains exhibited similar levels of efficacy against Ice $^{+} P$. syringae strains $(35,36)$. These observations, as well as the fact that Cit7 is effective against bacterial spot under greenhouse conditions, while TLP2 is not (M. Wilson, J. M. Byrne, H. L. Campbell, A. C. Dianese, J. B. Jones, and D. A. Cuppels, unpublished data), suggest that Cit7 may function via a different mechanism than TLP2.

The bacterial strain P. fluorescens A506, either derived from agar culture or from the formulated commercial product BlightBan A506, provided 0 to $40 \%$ reduction in foliar disease severity with a mean reduction of $18 \%$. P. fluorescens A506 also showed some evidence of ability to reduce incidence of bacterial speck on fruit. However, P. fluorescens A506 was not as effective as $P$. syringae Cit7 and lacks efficacy against bacterial spot (M. Wilson, J. M. Byrne, H. L. Campbell, A. C. Dianese, J. B. Jones, and D. A. Cuppels, unpublished data). Despite these limitations, the fact that $P$. fluorescens A506 is Ice $^{-}$would make it effective in preemptive exclusion of $\mathrm{Ice}^{+}$bacteria on the foliage of young transplants, protecting them from frost injury. Plus, it is already commercially available as BlightBan A506, which is registered for use on tomatoes; hence, it could be readily integrated into a disease/ pest control program on tomato.

It would be desirable to utilize the most successful biological control agents in an integrated pest management (IPM) program

TABLE 6. Efficacy of biological control agents in the control of bacterial speck (foliar severity) on tomato (cv. Agriset 761) in a field experiment conducted in Alabama (spring 1998)

\begin{tabular}{lccc}
\hline & Foliar severity $^{\mathrm{v}}$ & Foliar severity $^{\mathrm{w}}$ & Foliar severity $^{\mathrm{x}}$ \\
\hline Control & $1.70 \mathrm{a}^{\mathrm{y}}$ & $0.84 \mathrm{ab}^{\mathrm{y}}$ & $44.31 \mathrm{a}^{\mathrm{y}}$ \\
Mankocide & $1.40 \mathrm{c}(17.6)^{\mathrm{z}}$ & $0.85 \mathrm{ab}^{\mathrm{z}}(0)^{\mathrm{z}}$ & $26.06 \mathrm{~d}(41.2)^{\mathrm{z}}$ \\
$\begin{array}{l}\text { Pseudomonas } \\
\quad \text { syringae Cit7 }\end{array}$ & $1.53 \mathrm{bc}(10.0)$ & $0.87 \mathrm{a}(0)$ & $27.77 \mathrm{~cd}(37.3)$ \\
$\begin{array}{l}\text { P. syringae TLP2 } \\
P . \text { fluorescens A506 }\end{array}$ & $1.39 \mathrm{c}(18.2)$ & $0.95 \mathrm{a}(0)$ & $38.39 \mathrm{ab}(13.4)$ \\
\hline
\end{tabular}

v Sample of 20 leaflets per replicate taken 7 May 1998. Means are the log of the number of lesions per leaflet.

${ }^{\text {w Sample of }} 20$ leaflets per replicate taken 19 May 1998. Means are the log of the number of lesions per leaflet.

x Visual ratings of foliar disease severity (0 to 100\%) taken 26 May 1998. Numbers are arcsine transformed.

${ }^{y}$ Means in a column followed by the same letter are not significantly different at $P=0.05$ according to Duncan's multiple range test.

${ }^{\mathrm{z}}$ Percent disease reduction compared to pathogen-only control.

TABLE 5. Efficacy of biological control agents in the control of bacterial speck (foliar and fruit incidence) on tomato (cv. H9478) in a field experiment conducted in London, Ontario, Canada (summer 1997)

\begin{tabular}{|c|c|c|c|c|}
\hline & Foliar incidence $^{v}$ & Foliar severity ${ }^{\mathrm{w}}$ & Fruit incidence $^{\mathrm{x}}$ & Fruit yield (kg/10 plants) \\
\hline Control & $22.5 \mathrm{a}^{\mathrm{y}}$ & $45.0 \mathrm{a}^{\mathrm{y}}$ & $22.6 \mathrm{a}^{\mathrm{y}}$ & $47.4 \mathrm{a}^{\mathrm{y}}$ \\
\hline BlightBan A506 & $17.2 \mathrm{~b}(23.6)^{\mathrm{z}}$ & $27.0 \mathrm{~b}(40.0)^{\mathrm{z}}$ & $17.8 \mathrm{abc}(21.2)^{\mathrm{z}}$ & $48.9 \mathrm{a}$ \\
\hline Paenibacillus BC87 & $15.5 \mathrm{~b}(31.1)$ & $33.5 \mathrm{ab}(25.6)$ & $21.7 \mathrm{abc}(4.0)$ & $44.3 \mathrm{a}$ \\
\hline Pseudomonas syringae Cit7 & $14.7 \mathrm{~b}(34.7)$ & $26.0 \mathrm{~b}(42.2)$ & 24.8 a $(0)$ & $46.8 \mathrm{a}$ \\
\hline Actigard & $8.3 \mathrm{c}(63.1)$ & 10.5 c $(76.7)$ & $16.1 \mathrm{bc}(28.8)$ & $44.9 \mathrm{a}$ \\
\hline A506 + Actigard & $4.2 \mathrm{~d}(81.3)$ & $4.8 \mathrm{c}(89.3)$ & $14.6 \mathrm{c}(35.4)$ & $46.8 \mathrm{a}$ \\
\hline
\end{tabular}

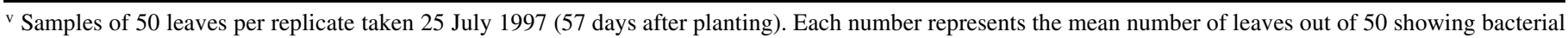
speck-like symptoms.

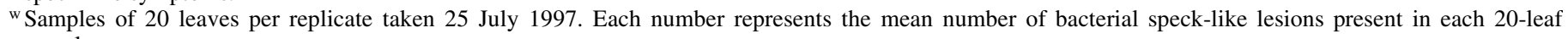
sample.

x Tomatoes were harvested on 12 September 1997 (106 days after planting), assessed for bacterial speck-like lesions, and weighed.

y Means in a column followed by the same letter are not significantly different at $P=0.05$ according to Duncan's multiple range test.

${ }^{\mathrm{z}}$ Percent disease reduction compared to pathogen-only control. 
with currently available chemicals or those that are likely to be available in the near future. Such integration has been successfully achieved with BlightBan A506 in the control of fire blight of pear, where the streptomycin-resistant biological control agent is applied in conjunction with the antibiotic (39). Unfortunately, none of the successful biological control agents employed in this study are naturally resistant to copper so that they could be integrated with the current standard chemical control regime of copper plus EBDC. There is potential, however, for the integration of the nonbactericidal plant activators with biological control agents. Under greenhouse conditions, the combined use of Cit7 and salicylic acid, which induces SAR in tomato (11), reproducibly provided significantly greater reductions in disease severity than either agent alone (27). Cit7 (Table 7) and P. fluorescens A506 (Table 5) exhibited potential for additive activity with Actigard in control of foliar disease severity. Most notably, the combination of A506 and Actigard was the only treatment that significantly reduced epiphytic $P$. syringae pv. tomato populations sizes. Despite these

TABLE 7. Efficacy of biological control agents in the control of bacterial speck (foliar severity) on tomato (cv. Agriset 761) in a field experiment conducted in Alabama (spring 1998)

\begin{tabular}{|c|c|c|c|}
\hline & Foliar severity ${ }^{v}$ & Foliar severityw & Foliar severity ${ }^{x}$ \\
\hline Control & $1.77 \mathrm{a}^{\mathrm{y}}$ & $0.73 \mathrm{a}^{\mathrm{y}}$ & $35.32 \mathrm{a}^{\mathrm{y}}$ \\
\hline Actigard & $1.16 \mathrm{~b}(34.5)^{\mathrm{z}}$ & $0.59 \mathrm{ab}(19.2)^{\mathrm{z}}$ & $22.59 \mathrm{~b}(36.0)^{\mathrm{z}}$ \\
\hline Pseudomonas syringae & & & \\
\hline $\begin{array}{c}\text { Cit7 + Actigard } \\
\text { P. syringae TLP2 + }\end{array}$ & 0.92 c (48.0) & $0.51 \mathrm{~b}(30.1)$ & $20.34 \mathrm{~b}(0.4)$ \\
\hline $\begin{array}{l}\text { Actigard } \\
\text { P. fluorescens A506 }\end{array}$ & $1.19 \mathrm{~b}(32.8)$ & $0.70 \mathrm{ab}(4.1)$ & $26.81 \mathrm{~b}(24.1)$ \\
\hline + Actigard & 1.14 b (35.6) & $0.63 \mathrm{ab}(13.7)$ & $22.40 \mathrm{~b}(36.6)$ \\
\hline
\end{tabular}

${ }^{\mathrm{v}}$ Sample of 20 leaflets per replicate taken 7 May 1998. Means are the log of the number of lesions per leaflet.

${ }^{\text {w Sample of }} 20$ leaflets per replicate taken 19 May 1998. Means are the $\log$ of the number of lesions per leaflet.

${ }^{x}$ Visual ratings of foliar disease severity (0 to 100\%) taken 26 May 1998. Numbers are arcsine transformed.

${ }^{y}$ Means in a column followed by the same letter are not significantly different at $P=0.05$ according to a Duncan's multiple range test.

${ }^{\mathrm{z}}$ Percent disease reduction compared to pathogen-only control.

TABLE 8. Summary of efficacy of biological control agents Pseudomonas syringae Cit7, P. syringae TLP2, and $P$. fluorescens A506 against bacterial speck of tomato in several locations in North America in 1996, 1997, and 1998

\begin{tabular}{|c|c|c|c|}
\hline \multirow[b]{2}{*}{$\begin{array}{l}\text { Experiment } \\
\text { (location and date) }\end{array}$} & \multicolumn{3}{|c|}{ Mean reduction in disease severity $(\%)$} \\
\hline & $\begin{array}{l}\text { P. syringae } \\
{\text { Cit } 77^{\mathrm{w}}}^{\text {s. }}\end{array}$ & $\begin{array}{l}\text { P. syringae } \\
\text { TLP2 }^{\mathrm{w}}\end{array}$ & $\begin{array}{l}\text { P. fluorescens } \\
\text { A506 }^{\mathrm{x}}\end{array}$ \\
\hline $\begin{array}{l}\text { Alabama (AL), spring } 1996 \\
\text { (Table 1) }\end{array}$ & 50.1 & 17.1 & 24.6 \\
\hline $\begin{array}{l}\text { Florida (FL) spring } 1996 \\
\text { (Table 2) }\end{array}$ & 24.5 & 28.4 & 24.0 \\
\hline $\begin{array}{l}\text { London, Ontario, Canada, (ON) } \\
\text { summer } 1996 \text { (Table 3) }\end{array}$ & 26.8 & 5.1 & 29.5 \\
\hline AL, spring 1997 (Table 4) & 15.0 & 14.7 & 9.6 \\
\hline AL, spring $1997 y$ & 24.0 & $\mathrm{ND}^{\mathrm{z}}$ & 15.5 \\
\hline FL, spring $1997^{y}$ & 18.9 & ND & ND \\
\hline California, spring $1997^{y}$ & 44.8 & ND & 0.0 \\
\hline ON, summer 1997 (Table 5) & 42.2 & ND & 40.0 \\
\hline AL, spring 1998 (Table 6) & 15.8 & 10.5 & 7.7 \\
\hline $\mathrm{AL}$, spring $1998^{\mathrm{y}}$ & 21.2 & 13.4 & 11.3 \\
\hline Mean & 28.3 & 14.9 & 18.0 \\
\hline
\end{tabular}

${ }^{\text {w }}$ Mean reduction in disease severity (\%) calculated across available severity ratings in specified field experiment.

${ }^{x}$ Mean of reduction in disease severity (\%) for P. fluorescens A506 and formulated BlightBan A506 combined across available severity ratings in specified field experiment.

y P. Ji, H. L. Campell, J. W. Kloepper, J. B. Jones, T. Suslow, and M. Wilson, unpublished data.

${ }^{\mathrm{z}} \mathrm{ND}=$ strain not included in this trial. promising results, many more trials will be required to determine whether there is a consistent benefit to using biological control agents in conjunction with Actigard.

Nonpathogenic hrp mutants have been found to significantly reduce disease severity in the case of several different pathogens, including Xanthomonas campestris pv. vesicatoria (45), Erwinia amylovora (21), and Ralstonia solanacearum (20,22). In this study, the $P$. syringae pv. tomato DC3000 hrpA, hrpH, and hrpS mutants all significantly reduced disease severity caused by wildtype DC3000 under greenhouse conditions, however, only the hrpS mutant significantly reduced disease severity under field conditions where disease was caused by indigenous $P$. syringae pv. tomato strains and/or PT12. In $P$. syringae, the hrpS-gene product plays a regulatory role and hence, in the $h r p S$ mutant the entire $h r p$ regulon, including $h r p$-associated $(h p a)$ genes, is probably not induced in planta. It is interesting to note that in two other pathogens, $X$. campestris pv. vesicatoria (45) and E. amylovora (21), the regulatory mutants also have provided the highest
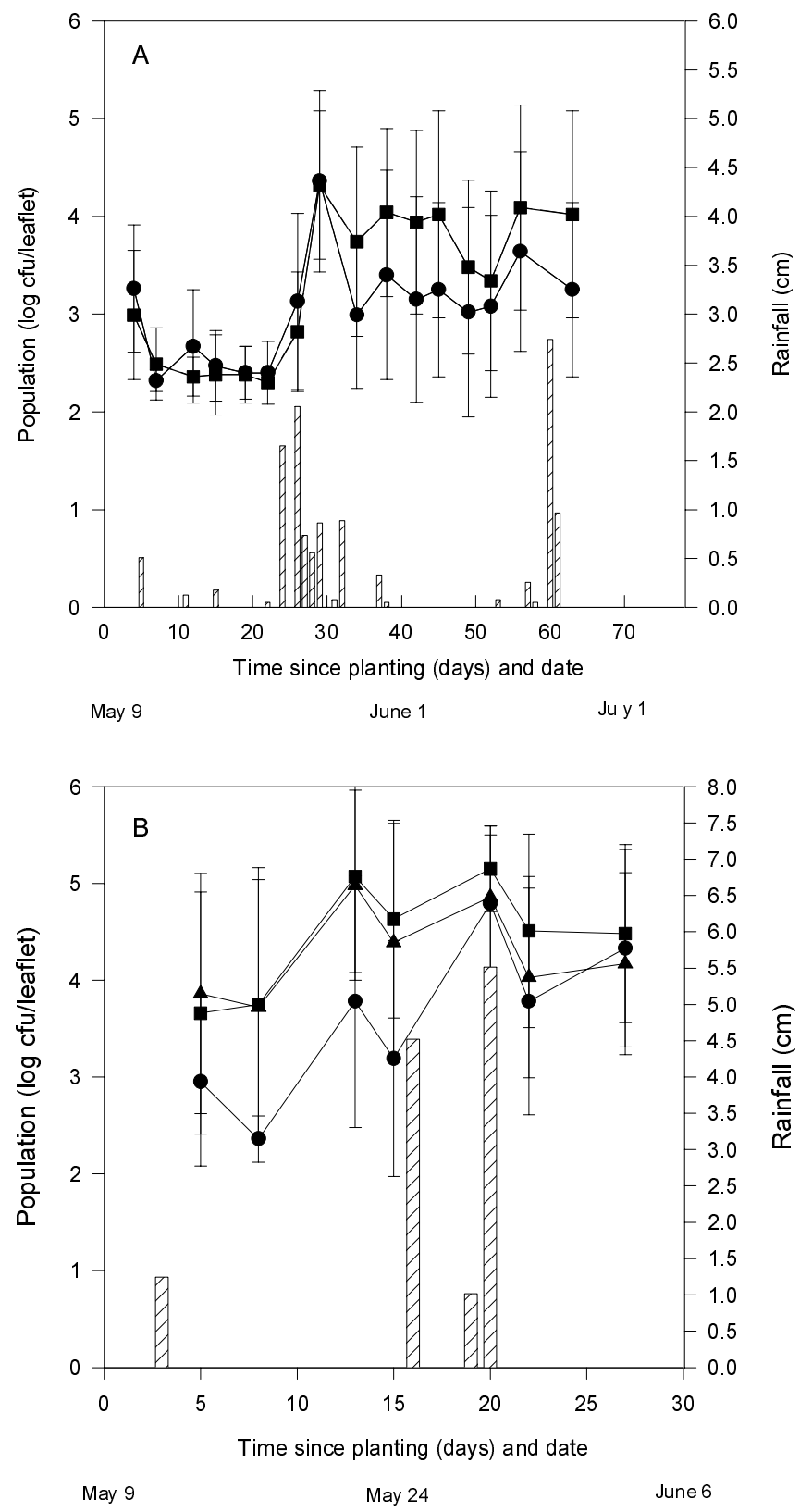

Fig. 1. Population dynamics of biological control agents Pseudomonas

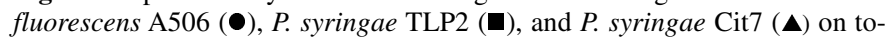
mato (cv. Agriset 761) under field conditions in Alabama and rainfall during experimental period of A, 1995 and B, 1996. 
levels of disease reduction (compared to strains with mutations in nonregulatory or structural genes) perhaps suggesting something about the mechanism of action in these mutants.

Despite the efficacy of the P. syringae pv. tomato hrpS mutant, hrp mutants were not employed in subsequent speck field trials due to lack of superiority to nonengineered naturally occurring strains (e.g., Cit7), the regulatory bureaucracy involved in fieldreleases, and the low probability that hrp mutants will be developed commercially in the United States in the near to mid-term future. This contrasts somewhat with the bacterial spot situation in which the $X$. campestris pv. vesicatoria hrpG mutant is more effective than any of the nonpathogenic strains and has warranted extensive examination under field conditions at different locations (45; W. P. Moss, J. B. Jones, and M. Wilson, unpublished data).

The greenhouse assays, particularly when replicated multiple times, successfully predicted the superior efficacy of $P$. syringae Cit7 over P. syringae TLP2 and P. fluorescens A506. However, the variability in efficacy observed suggests that a minimum of three repetitions are necessary to get a true picture of the potential of an

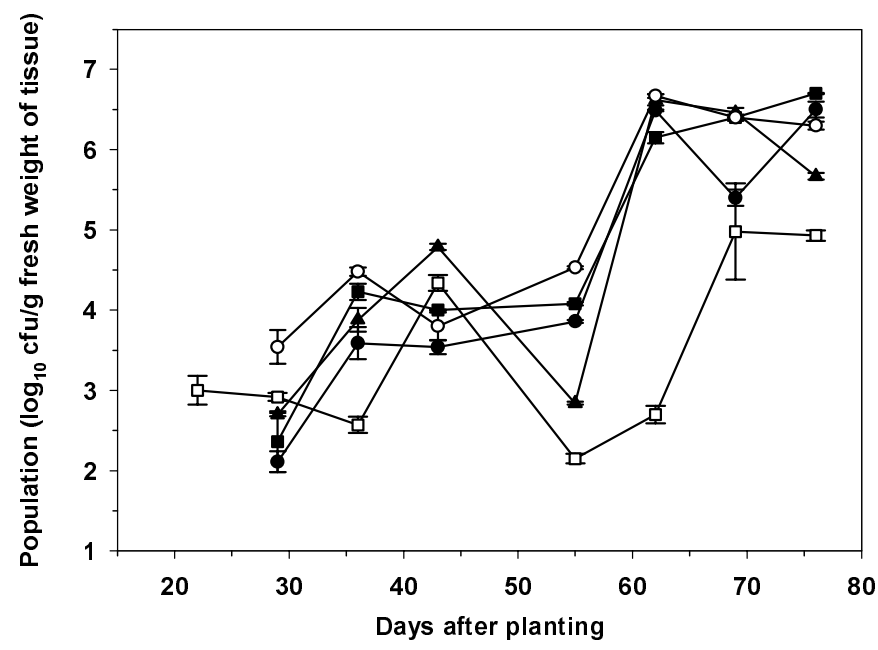

Fig. 2. Population dynamics of biological control agent and pathogen on tomato (cv. H9478) under field conditions in London, Ontario, Canada during the 1996 experiment. Population size of Pseudomonas fluorescens A506 ( $\square$ ); population size of $P$. syringae pv. tomato strain DCT6D1 on nontreated tomato plants $(O)$; and population size of $P$. syringae pv. tomato on tomato plants treated with biological control agent $P$. fluorescens A506 (匹), P. syringae TLP2 $(\bullet)$, and $P$. syringae Cit7 (ム). individual strain as evidenced by the fact that $\mathrm{Cu} 9$ and $\mathrm{Cu} 14$ gave relatively high levels of control in the first greenhouse assay, but the mean level of control after three replicate assays was fairly low. The need to screen such large numbers of bacterial strains in replicate greenhouse assays in order to select an organism with potential for field use makes this empirical approach impractical in most instances, underscoring the need to understand the attributes of an effective biological control agent for the targeted pathogen and the need to develop more targeted selection strategies.

Based upon our knowledge of the characteristics of $P$. syringae strains TLP2 and Cit7 (35), P. fluorescens A506 $(39,68)$, and the relative efficacy of these strains, we can speculate on some of the important characteristics of a successful biological control agent of bacterial speck of tomato. While $P$. syringae strains Cit7 and TLP2 and $P$. fluorescens strain A506 are not known to produce antibiotics effective against $P$. syringae pv. tomato, $P$. syringae strains have been reported to produce various bacteriocins $(30,65)$, and $P$. fluorescens A506 has been reported to produce an ironinducible antibiotic; hence, a role for an antimicrobial metabolite cannot be ruled out. It has been demonstrated that similarity in in vitro carbon source utilization profiles between the biological control agent and $P$. syringae pv. tomato is an important attribute of a successful biological control agent (28), however, TLP2 and Cit7 both have carbon source utilization profiles with a high degree of similarity to $P$. syringae pv. tomato; hence, differences in this area are unlikely to account for the superiority of Cit7 over TLP2. Neither were there significant differences in leaf surface colonization between TLP2 and Cit7 in AL experiments. One major difference between the two strains is that Cit7 was also effective against bacterial spot, while TLP2 was not (M. Wilson, J. M. Byrne, H. L. Campbell, A. C. Dianese, J. B. Jones, and D. A. Cuppels, unpublished data). In the case of bacterial spot, preemptive competitive exclusion of epiphytic $X$. campestris pv. vesicatoria populations appears less important than it is in $P$. syringae pv. tomato (45). It is possible that the effect of Cit7 against spot relates to the ability of Cit7 to partially invade the interior of the leaf in the manner of a pathogen without causing disease symptoms. Following vacuum infiltration into bean (Phaseolus vulgaris) leaves, Cit7 was able to multiply, though to a lower population size than pathogenic strains, while TLP2 was not (71). Further, the ability to multiply internally following vacuum infiltration was correlated with the ability to access internal sites following mist inoculation (71). The unique ability of Cit7 to invade certain internal sites without causing disease may lead to pre-
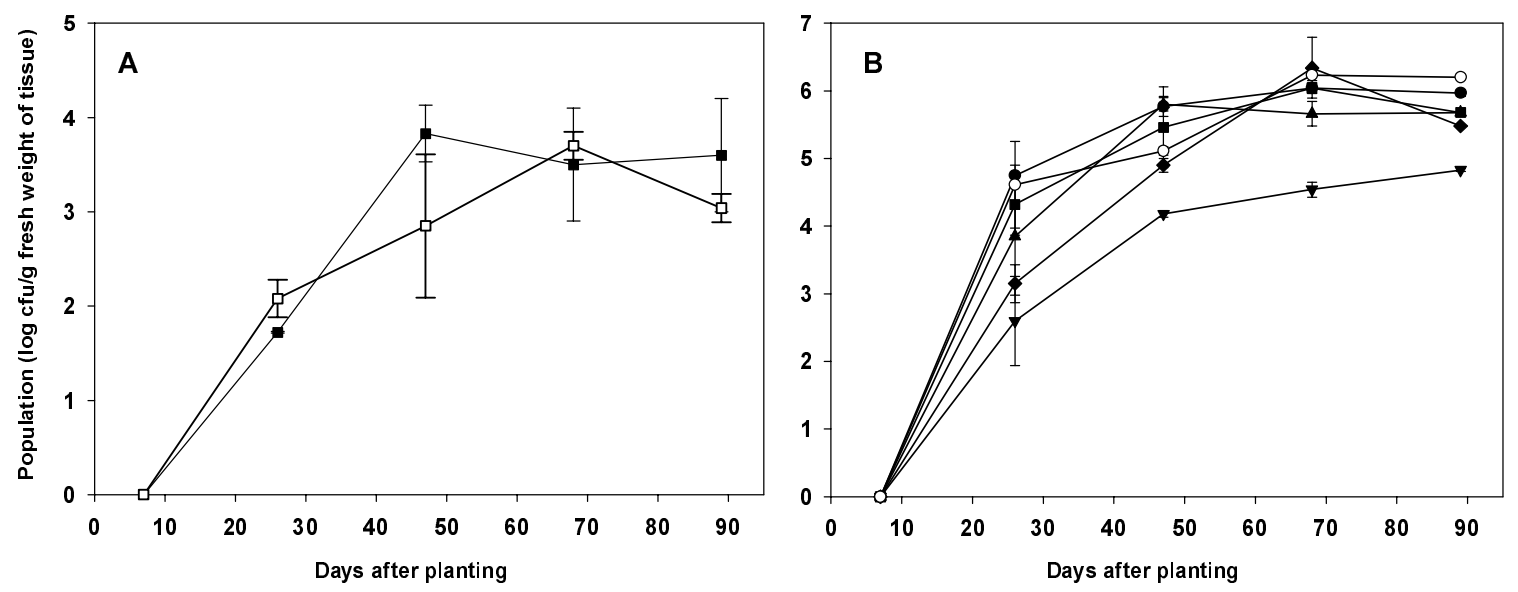

Fig. 3. A, Seasonal progression of the biological control agent Pseudomonas fluorescens A506 on bacterial speck-infected tomato (cv. H9478) plants grown

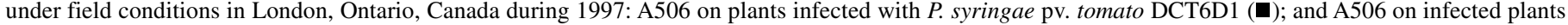
sprayed every 10 days with Actigard (62 mg/liter) ( $\square$ ). B, Effect of Actigard and various biological control agents on populations of $P$. syringae pv. tomato strain DCT6D1 sprayed on field tomato plants (cv. H9478) grown in London, Ontario, Canada in 1997: Control (O); P. fluorescens A506 (•); Paenibacillus sp.

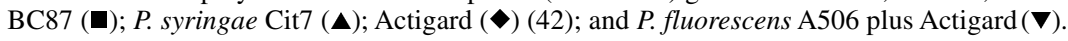


emptive exclusion of the pathogen from these internal sites or may induce host defense responses that contribute to the disease suppressive ability of this strain. In other words, in addition to the preemptive competitive exclusion of surface $P$. syringae pv. tomato populations, to which TLP2 and A506 are limited, Cit7 may have the ability to exclude internal populations or maybe to induce protective host defense responses in tomato. One might speculate, therefore, that the superior biological control agent of speck is one that has the ability to preemptively exclude both surface and internal $P$ syringae pv. tomato populations (71) or to additionally induce host defense responses.

\section{ACKNOWLEDGMENTS}

This work was supported by the USDA Southern Region IPM program (M. Wilson and J. B. Jones, USDA 95-34103-1541; M. Wilson, J. B. Jones, E. Sikora, and F. Louws, USDA 97-34103-4888) and additional support was provided to M. Wilson by Plant Health Technologies, Boise, ID and Campbells Research and Development, Davis, CA. Support for the work in Canada was provided to D. A. Cuppels by the Ontario Vegetable Growers Marketing Board. J. B. Jones wishes to thank R. O. Kelly for technical assistance with the field trials, and the authors wish to thank the Editor, D. Fravel, S. E. Lindow, and two anonymous reviewers for their comments on the manuscript.

\section{LITERATURE CITED}

1. Alexander, S. A., Kim, S. H., and Waldenmaier, C. M. 1999. First report of copper-tolerant Pseudomonas syringae pv. tomato in Virginia. Plant Dis. 83:964.

2. Babelegoto, N. M., Varvaro, L., and Cirulli, M. 1988. Epiphytic and endophytic multiplication of Pseudomonas syringae pv. tomato (Okabe) Young et al. in susceptible and resistant tomato leaves. Phytopathol. Mediterr. 27:138-144.

3. Backman, P. A., Wilson, M., and Murphy, J. F. 1997. Bacteria for biological control of plant diseases. Pages 95-109 in: Environmentally Safe Approaches to Crop Disease Control. N. A. Rechcigl and J. E. Rechcigl, eds. CRC Lewis Publishers, Boca Raton, FL.

4. Bashan, Y., and Bashan, de L. E. 2002. Protection of tomato seedlings against infection by using the plant growth-promoting bacterium Azospirillum brasilense. Appl. Environ. Microbiol. 68:2637-2643.

5. Bender, C. L., and Cooksey, D. A. 1986. Indigenous plasmids in Pseudomonas syringae pv. tomato: Conjugative transfer and role in copper resistance. J. Bacteriol. 165:534-541.

6. Bonn, W. G., Gitaitis, R. D., and MacNeill, B. H. 1985. Epiphytic survival of Pseudomonas syringae pv. tomato on tomato transplants shipped from Georgia. Plant Dis. 69:58-60.

7. Braun, A., Sands, D. C., and Jacobsen, B. J. 1997. Mechanisms in the biological control of Pseudomonas syringae pv. syringae by Pantoea agglomerans. Proc. Mol. Approaches Biol. Control. IOBC Biological Control Working Group. Delemont, Switzerland.

8. Braun-Kiewnick, A., Jacobsen, B. J., and Sands, D. C. 2000. Biological control of Pseudomonas syringae pv. syringae, the causal agent of basal kernel blight of barley, by antagonistic Pantoea agglomerans. Phytopathology 90:368-375.

9. Buonaurio, R., Stravato, V. M., and Cappelli, C. 1996. Occurrence of Pseudomonas syringae pv. tomato race 1 in Italy on Pto gene-bearing tomato plants. J. Phytopathol. 144:437-440.

10. Clare, B. G. 1993. Agrobacterium: Biological plant disease control. Pages 129-146 in: Advanced Engineered Pesticides. L. Kim, ed. Marcel Dekker, New York

11. Cokmus, C., and Sayar, A. H. 1991. Effect of salicylic acid on the control of bacterial speck of tomato caused by Pseudomonas syringae pv. tomato. J. Turk. Phytopathol. 20:27-32.

12. Colin, J. E. 1988. Antagonisme entre les Pseudomonas fluorescents et plusieurs pathovars de Pseudomonas syringae. Application comme methode de lutte contre la moucheture bacterienne de la tomate. EPPO Bull. 18:47-54.

13. Colin, J. E., and Chafik, Z. 1986. Comparison of biological and chemical treatments for control of bacterial speck of tomato under field conditions in Morocco. Plant Dis. 70:1048-1050.

14. Colin, J. E., Faissoili, M., and Azami, M. 1986. Influence des traitements biologiques et chimiques de protection sur les populations epiphytiques de Pseudomonas syringae pv. tomato. Meded. Fac. Landbouwwet. Rijksuniv. Gent 51:1387-1396.

15. Colin, J., Pussemier, L., and Diouf, A. M. 1984. Demonstration et application de l'antagonisme du a des Pseudomonas fluorescents sur des bacteries phytopathogenes. Meded. Fac. Landbouwwet. Rijksuniv. Gent 49:587-596.

16. Conlin, K. C., and McCarter, S. M. 1983. Effectiveness of selected chemicals in inhibiting Pseudomonas syringae pv. tomato in vitro and in controlling bacterial speck. Plant Dis. 67:639-644.

17. Cooksey, D. A. 1988. Reduction of infection by Pseudomonas syringae pv. tomato using a nonpathogenic, copper-resistant strain combined with a copper bactericide. Phytopathology 78:601-603.

18. Cuppels, D. A., and Elmhirst, J. 1999. Disease development and changes in the natural Pseudomonas syringae pv. tomato populations on field tomato plants. Plant Dis. 83:759-764.

19. Donner, S. C., and Barker, S. J. 1996. Pto resistance will not be effective in Australia. (Abstr.) 8th Int. Congr. Mol. Plant-Microbe Interact. Knoxville, TN.

20. Etchebar, C., Trigalet-Demery, D., van Gijsegem, F., Vasse, J., Trigalet, A. 1998. Xylem colonization by an $\mathrm{hrcV}^{-}$mutant of Ralstonia solanacearum is a key factor for the efficient biological control of tomato bacterial wilt. Mol. Plant-Microbe Interact. 11:869-877.

21. Faize, M., Tharaud, M., Brisset, M. N., and Paulin, J. P. 1999. Protective effect of hrp mutants of Erwinia amylovora against a virulent strain of the pathogen: Expression in several biological systems and preliminary mechanistic studies. Acta Hortic. 489:635-637.

22. Frey, P., Prior, P., Marie, C., Kotoujansky, A., Trigalet-Demery, D., and Trigalet, A. 1994. Hrp ${ }^{-}$mutants of Pseudomonas solanacearum as potential biocontrol agents of tomato bacterial wilt. Appl. Environ. Microbiol. 60:3175-3181

23. Goode, M. J., and Sasser, M. 1980. Prevention-The key to controlling bacterial spot and bacterial speck of tomato. Plant Dis. 64:831-834.

24. Habazar, T., and Rudolph, K. 1997. Studies on the resistance of tomato cultivars against Pseudomonas syringae pv. tomato races 0 and 1 . Pages 138-143 in: Pseudomonas syringae Pathovars and Related Pathogens. K. Rudolph, T. J. Burr, J. W. Mansfield, D. Stead, A. Vivian, and J. Kietzell, eds. Kluwer Academic Publishers, Dordrecht, Netherlands.

25. Hubbard, J. P. 1996. Occurrence of bacterial speck on Pto-carrying hybrid tomatoes in California during 1995 and 1996. Proc. 12th Annual Tomato Disease Workshop.

26. Ji, P., Kloepper, J. W., Wilson, M., and Campbell, H. L. 1996. Rhizobacterial-induced systemic resistance in tomato against bacterial speck. (Abstr.) Phytopathology 86(suppl.):S50.

27. Ji, P., and Wilson, M. 1997. Enhancement of population size and biocontrol effectiveness of biocontrol agents of bacterial speck of tomato by foliar salicylate amendment. (Abstr.) Phytopathology 87(suppl.):S48.

28. Ji, P., and Wilson, M. 2002. Assessment of the importance of similarity in carbon source utilization profiles between the biological control agent and pathogen in biological control of bacterial speck of tomato. Appl. Environ. Microbiol. 68:4383-4389.

29. King, E. O., Ward, M. K., and Raney, D. E. 1954. Two simple media for the demonstration of pyocyanin and fluorescein. J. Lab. Clin. Med. 44: 301-307.

30. Lavermicocca, P., Lonigro, S. L., Valerio, F., Evidente, A., and Visconti, A. 2002. Reduction of olive knot disease by a bacteriocin from Pseudomonas syringae pv. ciccaronei. Appl. Environ. Microbiol. 68:1403-1407.

31. Lawton, M. B., and MacNeill, B. H. 1986. Occurrence of race 1 of Pseudomonas syringae pv. tomato on field tomato in southwestern Ontario. Can. J. Plant Pathol. 8:85-88.

32. Lindemann, J., Arny, D. C., and Upper, C. D. 1984. Use of an apparent infection threshold population of Pseudomonas syringae to predict incidence and severity of brown spot of bean. Phytopathology 74:1334-1339.

33. Lindemann, J., and Suslow, T. V. 1987. Competition between ice nucleation-active wild type and ice nucleation-deficient deletion mutant strains of Pseudomonas syringae and P. fluorescens Biovar I and biological control of frost injury on strawberry blossoms. Phytopathology 77:882-886.

34. Lindow, S. E. 1983. Methods of preventing frost injury caused by epiphytic ice-nucleation-active bacteria. Plant Dis. 67:327-333.

35. Lindow, S. E. 1985. Ecology of Pseudomonas syringae relevant to the field use of Ice deletion mutants constructed in vitro for plant frost control. Pages 23-35 in: Engineered Organisms in the Environment: Scientific Issues. H. O. Halvorson, D. Pramer, and M. Rogul, eds. American Society for Microbiology, Washington, D.C.

36. Lindow, S. E. 1987. Competitive exclusion of epiphytic bacteria by IcePseudomonas syringae mutants. Appl. Environ. Microbiol. 53:25202527.

37. Lindow, S. E. 1993. Biological control of plant frost injury: The Ice story. Pages 113-128 in: Advanced Engineered Pesticides. L. Kim, ed. Marcel Dekker, New York.

38. Lindow, S. E., Hirano, S. S., Barchet, W. R., Arny, D. C., and Upper, C. D. 1982. Relationship between ice nucleation frequency of bacteria and 
frost injury. Plant Physiol. 70:1090-1093.

39. Lindow, S. E., McGourty, G., and Elkins, R. 1996. Interactions of antibiotics with Pseudomonas fluorescens A506 in the control of fire blight and frost injury to pear. Phytopathology 86:841-848.

40. Lindow, S. E., Willis, D. K., and Panopoulos, N. J. 1987. Biological control of bacterial brown spot disease of bean with Tn5-induced avirulent mutants of the pathogen. (Abstr.) Phytopathology 77:1768.

41. Lindow, S. E., and Wilson, M. 1999. Biological control of foliar pathogens and pests with bacterial biocontrol agents. Pages 642-650 in: Manual of Industrial Microbiology and Biotechnology, 2nd ed. A. L. Demain and J. E. Davies, eds. American Society of Microbiology Press, Washington, D.C.

42. Louws, F. J., Wilson, M., Campbell, H. L., Cuppels, D. A., Jones, J. B., Shoemaker, P. B., Sahin, F., and Miller, S. A. 2001. Field control of bacterial spot and bacterial speck of tomato using a plant activator. Plant Dis. 85:481-488.

43. May, R., Volksch, B., and Kampmann, G. 1997. Antagonistic activities of epiphytic bacteria from soybean leaves against Pseudomonas syringae pv. glycinea in vitro and in planta. Microbiol. Ecol. 34:118-124.

44. McCarter, S. M., Jones, J. B., Gitaitis, R. D., and Smitley, D. R. 1983. Survival of Pseudomonas syringae pv. tomato in association with tomato seed, soil, host tissue, and epiphytic weed hosts in Georgia. Phytopathology 73:1393-1398.

45. Moss, W. P., Bonas, U., Jones, J. B., and Wilson, M. Interactions of Xanthomonas axonopodis pv. vesicatoria 75-3 hrp mutants, the pathogenic parent, and the host plant. ICPP, Edinburgh, Scotland.

46. Oldroyd, G. E. D., and Staskawicz, B. J. 1998. Genetically engineered broad-spectrum disease resistance in tomato. Proc. Natl. Acad. Sci. 95:10300-10305.

47. Oldroyd, G., Suslow, T. V., Staskawicz, B., and Miyao, G. 1997. Pseudomonas syringae pv. tomato infecting Pto gene-bearing cultivars carry functional avrPto in CA. (Abstr.) Phytopathology 87(suppl.):S72.

48. Pernezny, K., Kudela, V., Kokoskova, B., and Hladka, I. 1995. Bacterial disease of tomato in the Czech and Slovak republics and lack of streptomycin resistance among copper-tolerant bacterial strains. Crop Prot. 14: 267-270.

49. Pitblado, R. E., and MacNeill, B. H. 1983. Genetic basis of resistance to Pseudomonas syringae pv. tomato in field tomatoes. Can. J. Plant Pathol. 5:251-255.

50. Pitblado, R. E., MacNeill, B. H., and Kerr, E. A. 1984. Chromosomal identity and linkage relationships of Pto, a gene for resistance to Pseudomonas syringae pv. tomato in tomato. Can. J. Plant Pathol. 6:48-53.

51. Saad, A. T., and Hassan, H. M. A. 2000. Pathogenesis and control of bacterial speck, Pseudomonas syringae pv. tomato, on tomato. EPPO Bull. 30:341-345

52. Sahin, F. 2001. Severe outbreaks of bacterial speck, caused by Pseudomonas syringae pv. tomato, on field-grown tomatoes in the eastern Anatolia region of Turkey. Plant Pathol. 50:799.

53. Scarponi, L., Buonaurio, R., and Martinetti, L. 2001. Persistence and translocation of a benzathiadiazole derivative in tomato plants in relation to systemic acquired resistance against Pseudomonas syringae pv. tomato. Pest. Manag. Sci. 57:262-268.

54. Schneider, R. W., and Grogan, R. G. 1977. Bacterial speck of tomato: Sources of inoculum and establishment of a resident population. Phytopathology 67:388-394.

55. Silva, V. L., da, and Lopes, C. A. 1995. Pseudomonas syringae pv. tomato resistant to streptomycin and oxytetracycline in tomato plants treated or not with agricultural antibiotics. Fitopatol. Bras. 20:80-84.
56. Silva, V. L., da, and Lopes, C. A. 1995. Pseudomonas syringae pv. tomato resistant to copper in copper-sprayed tomato fields. Fitopatol. Bras. 20:85-89.

57. Smitley, D. R., and McCarter, S. M. 1982. Spread of Pseudomonas syringae pv. tomato and role of epiphytic populations and environmental conditions in disease development. Plant Dis. 66:713-717.

58. Stout, M. J., Fidantsef, A. L., Duffey, S. S., and Bostock, R. M. 1999. Signal interactions in pathogen and insect attack: Systemic plant-mediated interactions between pathogens and herbivores of the tomato. Physiol. Mol. Plant Pathol. 54:115-130.

59. Tang, X., Xie, M., Kim, Y. J., Zhou, J., Klessig, D. F., and Martin, G. B. 1999. Over expression of Pto activates defense responses and confers broad resistance. Plant Cell 11:15-29.

60. Tharaud, M., Badouin, E., and Paulin, J. P. 1993. Protection against fire blight by avirulent strains of Erwinia amylovora: Modulation of the interaction by avirulent mutants. Acta Hortic. 338:321-327.

61. Trigalet, A., and Trigalet-Demery, D. 1990. Use of avirulent mutants of Pseudomonas solanacearum for the biological control of bacterial wilt of tomato. Physiol. Mol. Plant Pathol. 36:27-38.

62. Varvaro, L., and Martella, L. 1993. Virulent and avirulent isolates of Pseudomonas syringae subsp. savastanoi as colonizers of olive leaves: Evaluation of possible biological control of the olive knot pathogen. EPPO Bull. 23:423-427.

63. Volksch, B., and May, R. 2001. Biological control of Pseudomonas syringae pv. glycinea by epiphytic bacteria under field conditions. Microbiol. Ecol. 41:132-139.

64. Volksch, B., Nuske, J., and May, R. 1996. Characterization of two epiphytic bacteria from soybean leaves with antagonistic activities against Pseudomonas syringae pv. glycinea. J. Basic Microbiol. 36:453-462.

65. Volksch, B., and Weingart, H. 1998. Toxin production by pathovars of Pseudomonas syringae and their antagonistic activities against epiphytic microorganisms. J. Basic Microbiol. 38:135-145.

66. Voloudakis, A. E., Gitaitis, R. D., Westbrook, J. K., Phatak, S. C., and McCarter, S. M. 1991. Epiphytic survival of Pseudomonas syringae pv. syringae and $P$. s. tomato on tomato transplants in southern Georgia. Plant Dis. 75:672-675.

67. Wilson, M. 1997. Biocontrol of aerial plant diseases in agriculture and horticulture: Current approaches and future prospects. J. Ind. Microbiol. Biotechnol. 19:188-191.

68. Wilson, M. 1998. Mechanisms of antagonism and strategies of biological control of plant diseases by P. fluorescens A506. Pages 78-80 in: Proc. First California Conf. Biol. Control. M. S. Hoddle, ed. Berkeley, CA.

69. Wilson, M. Management of bacterial diseases of plants: Biological control. Dekker Encylcopedia of Crop Science. R. M. Goodman, ed. Marcel Dekker, Inc., New York. (In press).

70. Wilson, M., and Backman, P. A. 1999. Biological control of plant pathogens. Pages 309-335 in: Handbook of Pest Management. J. R. Ruberson, ed. Marcel Dekker, Inc., New York.

71. Wilson, M., Hirano, S. S., and Lindow, S. E. 1999. Location and survival of leaf-associated bacteria in relation to pathogenicity and potential for growth within the leaf. Appl. Environ. Microbiol. 65:1435-1443.

72. Wilson, M., Moss, W. P., Ji, P., Wang, S.-Y., Dianese, A. C., Zhang, D., and Campbell, H. L. 1998. Molecular approaches in the development of biocontrol agents of foliar and floral bacterial pathogens. IOBC Bull. 21:247-255.

73. Yunis, H., Bashan, Y., Okon, Y., and Henis, Y. 1980. Weather dependence, yield losses, and control of bacterial speck of tomato caused by Pseudomonas tomato. Plant Dis. 64:937-939. 